\title{
ON SOME PROPERTIES OF SOLUTIONS TO ONE CLASS OF EVOLUTION SOBOLEV TYPE MATHEMATICAL MODELS IN QUASI-SOBOLEV SPACES
}

\author{
A.A. Zamyshlyaeva, South Ural State University, Chelyabinsk, Russian Federation, \\ alzama@mail.ru,
} J.K.T. Al-Isawi, South Ural State University, Chelyabinsk, Russian Federation, jtahir71@gmail.ru

\begin{abstract}
Interest in Sobolev type equations has recently increased significantly, moreover, there arose a necessity for their consideration in quasi-Banach spaces. The need is dictated not so much by the desire to fill up the theory but by the aspiration to comprehend nonclassical models of mathematical physics in quasi-Banach spaces. Notice that the Sobolev type equations are called evolutionary if solutions exist only on $\mathbb{R}_{+}$.

The theory of holomorphic degenerate semigroups of operators constructed earlier in Banach spaces and Frechet spaces is transferred to quasi-Sobolev spaces of sequences. This article contains results about existence of the exponential dichotomies of solutions to evolution Sobolev type equation in quasi-Sobolev spaces. To obtain this result we proved the relatively spectral theorem and the existence of invariant spaces of solutions.

The article besides the introduction and references contains two paragraphs. In the first one, quasi-Banach spaces, quasi-Sobolev spaces and polynomials of Laplace quasioperator are defined. Moreover the conditions for existence of degenerate holomorphic operator semigroups in quasi-Banach spaces of sequences are obtained. In other words, we prove the first part of the generalization of the Solomyak - Iosida theorem to quasiBanach spaces of sequences. In the second paragraph the phase space of the homogeneous equation is constructed. Here we show the existence of invariant spaces of equation and get the conditions for exponential dichotomies of solutions.
\end{abstract}

Keywords: holomorphic degenerate semigroups; quasi-Banach spaces; quasi-Sobolev spaces; invariant space; exponential dichotomy of solution.

Introduction. Let $\mathfrak{U}$ be a Banach space, $\mathcal{L}(\mathfrak{U})$ be a space of linear and bounded operators. Mapping $U \in C(\mathbb{R} ; \mathcal{L}(\mathfrak{U}))$ is called a semigroup of operators if for all $s, t \in \mathbb{R}_{+}$

$$
U^{s} U^{t}=U^{s+t} .
$$

Usually a semigroup is identified with its graph $\left\{U^{t}: t \in \mathbb{R}_{+}\right\}$. A semigroup $\left\{U^{t}: t \in\right.$ $\left.\mathbb{R}_{+}\right\}$is called holomorphic if it can be analitically continued to some sector of complex plane containing half axis $\mathbb{R}_{+}$preserving property (1). A holomorphic semigroup is called degenerate if its unit $P=s-\lim _{t \rightarrow 0+} U^{t}$ is a projector in $\mathfrak{U}$.

Firstly holomorphic degenerate semigroups appeared in $[1,2]$ as solving semigroups for evolution Sobolev type equation

$$
L \dot{u}=M u
$$

where operator $L \in \mathcal{L}(\mathfrak{U} ; \mathfrak{F})$, and operator $M \in C l(\mathfrak{U} ; \mathfrak{F}), \mathfrak{F}$ is a Banach space. Explicit theory of such semigroups can be found in [3].

Interest in Sobolev type equations has recently increased significantly [4-6], moreover, there arose a necessity for their consideration in quasi-Banach spaces. The need is dictated 
not so much by the desire to fill up the theory but by the aspiration to comprehend nonclassical models of mathematical physics [7] in quasi-Banach spaces [8].

Since the Cauchy problem for the Sobolev type equation is not solvable for arbitrary initial data it is necessary to construct the phase space of equation as the set of admissible initial values containing all solutions of equation [3]. The phase spaces of evolution and dynamical Sobolev type equations were constructed earlier in Banach spaces [3]. Moreover there were found conditions when the phase space splits into direct sum of invariant with respect to equation spaces and the solutions have exponential dichotomies [9]. By now these problems are completely solved in Banach spaces [6]. Our goal is to spread these ideas to one class of evolution Sobolev type equations in quasi-Banach spaces of sequences.

1. Holomorphic Degenerate Semigroups of Operators. Let $\mathfrak{U}$ be a lineal over $\mathbb{R}$. An ordered pair $\left(\mathfrak{U}_{\mathfrak{U}}\|\cdot\|\right)$ is called a quasi-normed space, if the function $\mathfrak{U}\|\cdot\|: \mathfrak{U} \rightarrow \mathbb{R}$ satisfies the following conditions:

1. $\mathfrak{U}\|u\| \geq 0$ for all $u \in \mathfrak{U}$, moreover $\mathfrak{U}\|u\|=0$ iff $u=\mathbf{0}$, where $\mathbf{0}$ is a zero element in $\mathfrak{U}$;

2. $\mathfrak{U}\|\alpha u\|=|\alpha|_{\mathfrak{U}}\|u\|$ for all $u \in \mathfrak{U}, \alpha \in \mathbb{R}$;

3. $\mathfrak{U}\|u+v\|=\mathrm{C}(\mathfrak{U}\|u\|+\mathfrak{U}\|v\|)$ for all $u, v \in \mathfrak{U}$, where the constant $C \geq 1$.

The function $\mathfrak{u}\|u\|$ with properties (i)-(iii) is called a quasi-norm. Obviously, in case $C=1$ this function is a norm.

The metrizable complete quasi-normed space is called a quasi-Banach space. The spaces of sequences $\ell_{q}, q \in(0,1)$ are well known quasi-Banach spaces (for $q \in[1,+\infty$ ) the spaces $\ell_{q}$ are Banach spaces).

Let henceforth $\left\{\lambda_{k}\right\} \subset \mathbb{R}_{+}$be a monotone sequence such that $\lim _{k \rightarrow \infty} \lambda_{k}=+\infty$. The quasi-Banach space

$$
\ell_{q}^{m}=\left\{u=\left\{u_{k}\right\}: \sum_{k=1}^{\infty}\left(\lambda_{k}^{\frac{m}{2}}\left|u_{k}\right|\right)^{q}<+\infty\right\}
$$

with a quasi-norm ${ }_{q}^{m}\|u\|=\left(\sum_{k=1}^{\infty}\left(\lambda_{k}^{\frac{m}{2}}\left|u_{k}\right|\right)^{q}\right)^{1 / q}, m \in \mathbb{R}$ is called a quasi-Sobolev space.

Obviously, for $q \in[1,+\infty)$ the spaces $\ell_{q}^{m}$ are Banach spaces; $\ell_{q}^{0}=\ell_{q}$, and there is a dense and continuous embedding $\ell_{q}^{n}$ into $\ell_{q}^{m}$ for $n>m$ and $q \in \mathbb{R}_{+}$.

Example 1. Let $\mathfrak{U}=\ell_{q}^{m+2 n}, \mathfrak{F}=\ell_{q}^{m} ; Q_{n}(\lambda)$ be a polynomial of power $n$. Consider operator $Q_{n}(\Lambda) u=\left\{Q_{n}\left(\lambda_{k}\right) u_{k}\right\}, n \in \mathbb{N}$, where $\left\{u_{k}\right\} \in \mathfrak{U}$. It is easy to see that operator $Q_{n}(\Lambda) \in \mathcal{L}(\mathfrak{U} ; \mathfrak{F})$, moreover $Q_{n}(\Lambda): \ell_{q}^{m+2 n} \rightarrow \ell_{q}^{m}$ is a toplinear isomorphism.

Let $\mathfrak{U}$ and $\mathfrak{F}$ be quasi-Banach spaces, operators $L \in \mathcal{L}(\mathfrak{U} ; \mathfrak{F})$ and $M \in C l(\mathfrak{U} ; \mathfrak{F})$, following [1], [2], take into consideration L-resolvent set $\rho^{L}(M)=\left\{\mu \in \mathbb{C}:(\mu L-M)^{-1} \in\right.$ $\mathcal{L}(\mathfrak{F} ; \mathfrak{U})\}$ and $L$-spectrum $\sigma^{L}(M)=\mathbb{C} \backslash \rho^{L}(M)$ of operator $M$. It is easy to show that the set $\rho^{L}(M)$ is always opened, therefore the $L$-spectrum of operator $M$ is always closed.

Definition 1. Operator $M$ is called strongly $(L, p)$-sectorial, $p \in\{0\} \cup \mathbb{N}$, if

(i) there exist constants $a \in \mathbb{R}$ and $\theta \in(\pi / 2 ; \pi)$ such that the sector

$$
S_{a, \theta}^{L}(M)=\{\mu \in \mathbb{C}:|\arg (\mu-a)|<\theta, \mu>a\} \subset \rho^{L}(M) ;
$$


(ii) there exists a constant $K \in \mathbb{R}_{+}$such that

$$
\max \left\{\mathcal{L}(\mathfrak{U})\left\|R_{(\mu, p)}^{L}(M)\right\|, \mathcal{L}(\mathfrak{F})\left\|L_{(\mu, p)}^{L}(M)\right\|\right\} \leq \frac{K}{\prod_{k=0}^{p}\left|\mu_{k}-a\right|}
$$

for $\quad$ all $\mu_{0}, \mu_{1}, \ldots, \mu_{p} \in S_{a, \theta}^{L}(M)$. Here $R_{(\mu, p)}^{L}(M)=\prod_{k=0}^{p} R_{\mu_{k}}^{L}(M)$ is the right and $L_{(\mu, p)}^{L}(M)=\prod_{k=0}^{p} L_{\mu_{k}}^{L}(M)$ is the left $(L, p)$-resolvent of operator $M$, and $R_{\mu}^{L}(M)=(\mu L-M)^{-1} L$ and $L_{\mu}^{L}(M)=L(\mu L-M)^{-1}$ are the right and the left $L$-resolvents of operator $M$ respectively.

(iii) there exists a dense in $\mathfrak{F}$ lineal $\mathfrak{F}^{0}$ such that

$$
\mathfrak{F}\left\|M(\lambda L-M)^{-1} L_{(\mu, p)}^{L}(M) f\right\| \leq \frac{\text { const }}{|\lambda| \prod_{k=0}^{p}\left|\mu_{k}\right|} \text { for all } f \in \mathfrak{F}^{0},
$$

where const $=\operatorname{const}(f)$; for all $\lambda, \mu_{k} \in S_{\theta}^{L}(M), k=0, \ldots, p$.

(iv)

$$
\mathcal{L}(\mathfrak{F} ; \mathfrak{L})\left\|(\lambda L-M)^{-1} L_{(\mu, p)}^{L}(M)\right\| \leq \frac{\text { const }}{|\lambda| \prod_{k=0}^{p}\left|\mu_{k}\right|}
$$

for arbitrary $\lambda, \mu_{k} \in S_{\theta}^{L}(M), k=0, \ldots, p$ and some const $\in \mathbb{R}_{+}$.

Example 2. Let $\mathfrak{U}=\ell_{q}^{m+2 n}, \mathfrak{F}=\ell_{q}^{m}, m \in \mathbb{R}, q \in \mathbb{R}_{+}, Q_{n}(\lambda)=\sum_{i=0}^{n} c_{i} \lambda^{i} R_{s}(\lambda)=\sum_{j=0}^{s} d_{j} \lambda^{j}$ be polynomials of powers $n$ and $s$ respectively $(n<s)$ with real coefficients $\left(\frac{d_{s}}{c_{n}}<0\right)$, without common roots. Construct operators $L=Q_{n}(\Lambda), M=R_{s}(\Lambda)$ as in example 1 . It is easy to show that $R_{s}(\Lambda) \in \mathcal{C l}(\mathfrak{U} ; \mathfrak{F}), \operatorname{dom} R_{s}(\Lambda)=\ell_{q}^{m+2 s}$, the $L$-spectrum $\sigma^{L}(M)$ of operator $M$ consists of points $\mu_{k}=R_{s}\left(\lambda_{k}\right)\left(Q_{n}\left(\lambda_{k}\right)\right)^{-1}, k \in \mathbb{N}: \lambda_{k}$ is not the root of the polynomial $Q_{n}(\lambda)$.

Lemma 1. [10] Operator $M$ defined in example 2 is strongly (L,0)-sectorial.

Theorem 1. [10] Let operators $M$ and $L$ be defined as in example 2. Then

(i) operators $L$ and $M$ generate holomorphic semigroups $\left\{U^{t}: t \in \mathbb{R}_{+}\right\}$and $\left\{F^{t}: t \in\right.$ $\left.\mathbb{R}_{+}\right\}$on spaces $\mathfrak{U}$ and $\mathfrak{F}$ respectively given by

$$
U^{t}=\frac{1}{2 \pi i} \int_{\Gamma} R_{\mu}^{L}(M) e^{\mu t} d \mu \in \mathcal{L}(\mathfrak{U}) \quad F^{t}=\frac{1}{2 \pi i} \int_{\Gamma} L_{\mu}^{L}(M) e^{\mu t} d \mu \in \mathcal{L}(\mathfrak{F})
$$

for $t \in \mathbb{R}_{+}$, where the contour $\Gamma \subset \rho^{L}(M)$ is such that $|\arg \mu| \rightarrow \theta$ npu $\mu \rightarrow \infty, \mu \in \Gamma$.

(ii) there exist semigroup's units which are the projectors $P \in \mathcal{L}(\mathfrak{U})$ and $Q \in \mathcal{L}(\mathfrak{F})$ given by

$$
P= \begin{cases}\mathbb{I}, & \text { if } \lambda_{k} \text { is not the root of } Q_{n}(\lambda) \text { for all } k \in \mathbb{N} \\ \mathbb{I}-\sum_{k \in \mathbb{N}: k=\ell}<., e_{k}>e_{k}, & \text { if there exist } \ell \in \mathbb{N}: \lambda_{\ell} \text { is the root of } Q_{n}(\lambda),\end{cases}
$$

(the projector $Q$ has the same form), splitting the quasi-Banach spaces $\mathfrak{U}$ and $\mathfrak{F}$ into direct sums

$$
\mathfrak{U}=\mathfrak{U}^{0} \oplus \mathfrak{U}^{1}, \quad \mathfrak{F}=\mathfrak{F}^{0} \oplus \mathfrak{F}^{1} ;
$$

(iii) there is splitting of operator actions $L_{k} \in \mathcal{L}\left(\mathfrak{U}^{k} ; \mathfrak{F}^{k}\right), M_{k} \in C l\left(\mathfrak{U}^{k} ; \mathfrak{F}^{k}\right), k=0,1$, and existence of operators $M_{0}^{-1} \in \mathcal{L}\left(\mathfrak{F}^{0} ; \mathfrak{U}^{0}\right), L_{1}^{-1} \in \mathcal{L}\left(\mathfrak{F}^{1} ; \mathfrak{U}^{1}\right)$; 
(iv) operators $H=M_{0}^{-1} L_{0}\left(G=L_{0} M_{0}^{-1}\right)$ are nilpotent and operators $S=L_{1}^{-1} M_{1}$ : $\operatorname{dom} M \cap$ $\mathfrak{U}^{1} \rightarrow \mathfrak{U}^{1}$ and $T=M_{1} L_{1}^{-1}: M[\operatorname{dom} M] \cap \mathfrak{F}^{1} \rightarrow \mathfrak{F}^{1}$ are sectorial.

2. Invariant Spaces and Exponential Dichotomies of Solutions. Let $\mathfrak{U}$ and $\mathfrak{F}$ be quasi-Sobolev spaces of sequences, operators $L \in \mathcal{L}(\mathfrak{U} ; \mathfrak{F})$ and $M \in C l(\mathfrak{U} ; \mathfrak{F})$ be constructed in example 2. Consider linear evolution Sobolev type equation

$$
L \dot{u}=M u \text {. }
$$

Vector-function $u \in C^{1}\left(\mathbb{R}_{+} ; \mathfrak{U}\right)$, satisfying (4) pointwise is called (a classical solution of this equation. The solution $u=u(t)$ of (4) is called a solution to the weakened Cauchy problem (in sense of S.G. Krein), if in addition for $u_{0} \in \mathfrak{U}$

$$
\lim _{t \rightarrow 0+} u(t)=u_{0}
$$

holds.

Definition 2. The set $\mathfrak{P} \subset \mathfrak{U}$ is called a phase space of equation (4), if

(i) any solution $u=u(t)$ of (4) lies in $\mathfrak{P}$ pointwise, i.e. $u(t) \in \mathfrak{P}$ for all $t \in \mathbb{R}_{+}$;

(ii) for all $u_{0} \in \mathfrak{P}$ there exists a unique solution to (4), (5).

Theorem 2. [10] Let operators $M$ and $L$ be defined as in example (2). Then the subspace $\mathfrak{U}^{1}$ is a phase space of $(4)$.

Consider the following condition:

Let $\sigma^{L}(M)=\sigma_{1}^{L}(M) \cup \sigma_{2}^{L}(M)$ and $\sigma_{1}^{L}(M)$ is not empty, $\left.\begin{array}{l}\text { there exists a bounded domain } \Omega_{1} \subset \mathbb{C} \text { with a boundary of class } C^{1}, \\ \text { such that } \Omega_{1} \supset \sigma_{1}^{L}(M) \text { and } \bar{\Omega}_{1} \bigcap \sigma_{2}^{L}(M) \text { is empty. }\end{array}\right\}$

If this condition holds then there exist [11] operators given by integrals

$$
P_{1}=\frac{1}{2 \pi i} \int_{\gamma_{1}} R_{\mu}^{L}(M) d \mu \text { and } Q_{1}=\frac{1}{2 \pi i} \int_{\gamma_{1}} L_{\mu}^{L}(M) d \mu,
$$

where $\gamma_{1}=\partial \Omega_{1}$. By construction operators $P_{1} \in \mathcal{L}(\mathfrak{U})$ and $Q_{1} \in \mathcal{L}(\mathfrak{F})$.

Lemma 2. Let $L, M \in \mathcal{L}(\mathfrak{U} ; \mathfrak{F})$ be defined in example 2 and condition (6) hold then operators $P_{1} \in \mathcal{L}(\mathfrak{U})$ and $Q_{1} \in \mathcal{L}(\mathfrak{F})$ are projectors in corresponding spaces.

Put $\mathfrak{U}^{11}=\operatorname{im} P_{1}, \mathfrak{F}^{11}=\operatorname{im} Q_{1}, \mathfrak{U}^{10}=\operatorname{ker} P_{1}, \mathfrak{F}^{10}=\operatorname{ker} Q_{1}$; and by $L_{11}\left(M_{11}\right)$ denote restriction of operator $L(M)$ onto $\mathfrak{U}^{11}$.

Theorem 3. Let conditions of lemma 2 be fulfilled. Then

(i) operators $L_{11}, M_{11} \in \mathcal{L}\left(\mathfrak{U}^{11} ; \mathfrak{F}^{11}\right)$;

(ii) there exists an operator $L_{11}^{-1} \in \mathcal{L}\left(\mathfrak{F}^{11} ; \mathfrak{U}^{11}\right)$.

Proof. Statement (i) follows from the construction of operators $P_{1} \in \mathcal{L}(\mathfrak{U})$ and $Q_{1} \in \mathcal{L}(\mathfrak{F})$, since $L P_{1}=Q_{1} L=L_{11}$ and $M P_{1}=Q_{1} M=M_{11}$.

Statement (ii) follows from theorem 1 since operator $L_{11}^{-1}$ is equal to restriction of operator $\frac{1}{2 \pi i} \int(\mu L-M)^{-1} d \mu$ onto subspace $\mathfrak{F}^{11}$. 
Corollary 1. Let conditions of lemma 2 be fulfilled. Then $P_{1}=P P_{1}=P_{1} P$ and $Q_{1}=$ $Q Q_{1}=Q_{1} Q$.

Construct operators $P_{2}=P-P_{1}$ and $Q_{2}=Q-Q_{1}$. Due to corollary 1 these operators are projectors. Put $\mathfrak{U}^{12}=\operatorname{im} P_{2}, \mathfrak{F}^{12}=\operatorname{im} Q_{2}$ and by $L_{12}\left(M_{12}\right)$ denote restriction of operator $L(M)$ onto $\mathfrak{U}^{12}$.

Corollary 2. Let conditions of lemma 2 be fulfilled. Then

(i) $\mathfrak{U}=\mathfrak{U}^{0} \oplus \mathfrak{U}^{1}, \quad \mathfrak{F}=\mathfrak{F}^{0} \oplus \mathfrak{F}^{1}, \quad \mathfrak{U}^{1}=\mathfrak{U}^{11} \oplus \mathfrak{U}^{12}, \quad \mathfrak{F}^{1}=\mathfrak{F}^{11} \oplus \mathfrak{F}^{12}$

(ii) operators $L_{12}, M_{12} \in \mathcal{L}\left(\mathfrak{U}^{12} ; \mathfrak{F}^{12}\right)$;

(iii) there exists an operator $L_{12}^{-1} \in \mathcal{L}\left(\mathfrak{F}^{12} ; \mathfrak{U}^{12}\right)$.

Definition 3. Let $\mathfrak{P}$ be a phase space of (4). The subset $\mathfrak{J} \subset \mathfrak{P}$ is called an invariant space of equation (4), if for arbitrary $u_{0} \in \mathfrak{J}$ the solution $u=u(t)$ of $(4),(5)$ lies in $\mathfrak{J}$ pointwise (i.e. $u(t) \in \mathfrak{J}$ for all $t \in R_{+}$).

Theorem 4. Let operators $L, M \in \mathcal{L}(\mathfrak{U} ; \mathfrak{F})$ be defined as in example 2 and condition (6) hold then the image of group

$$
V^{t}=\frac{1}{2 \pi i} \int_{\gamma_{1}} R_{\mu}^{L}(M) e^{\mu t} d \mu, t \in R
$$

is an invariant space of (4).

Proof. The statement follows from equality $\operatorname{im} V^{\bullet}=\operatorname{im} P_{1}=\mathfrak{U}^{11}$, that follows from theorem 2, corollaries 1 and 2 .

Definition 4. We say that solutions of (4) have exponential dichotomy, if

(i) the phase space of (4) can be represented as $\mathfrak{P}=\mathfrak{J}^{1} \oplus \mathfrak{J}^{2}$, where $\mathfrak{J}^{1(2)}$ are invariant spaces of equation (4);

(ii) for arbitrary $u_{0} \in \mathfrak{J}^{1}\left(u_{0} \in \mathfrak{J}^{2}\right)$ solution $u=u(t)$ of $(4)$, (5) is such that $\mathfrak{U}\|u(t)\| \leq$ $C_{1}\left(u_{0}\right) e^{-a t}\left(\mathfrak{u}\|u(t)\| \geq C_{2}\left(u_{0}\right) e^{a t}\right)$ for some $a>0$ and all $t \in R_{+}$.

Theorem 5. Let operators $L, M \in \mathcal{L}(\mathfrak{U} ; \mathfrak{F})$ be defined as in example 2 and condition

$$
\sigma^{L}(M) \cap i \mathbb{R}=\emptyset
$$

hold. Then solutions of (4) have exponential dichotomy.

Proof. The estimates of solutions can be received in dependence of location of components of $L$-spectrum of operator $M$. Due to condition (5) we can consider $\sigma_{1}^{L}(M)$ containing the points of $L$-spectrum of operator $M$ located in the right halfplane and construct projectors $P_{1}, P_{2}$ and invariant spaces $\mathfrak{J}^{1}, \mathfrak{J}^{2}$ respectively. Obviously, the needed estimates for solutions hold.

\section{References}

1. Sviridyuk G.A. On the General Theory of Operator Semigroups. Russian Mathematical Surveys, 1994, vol. 49, no. 4, pp. 45-74. DOI: 10.1070/RM1994v049n04ABEH002390

Вестник ЮУрГУ. Серия «Математическое моделирование

и програм мирование» (Вестник ЮУрГУ ММП). 2015. Т. 8, № 4. С. 113-119 
2. Sviridyuk G.A. Phase Spaces of Semilinear Sobolev Type Equations with Relatively Strongly Sectorial Operator. Algebra I Analiz, 1994, vol. 6, no 5, pp. 252-272. (in Russian)

3. Sviridyuk G.A., Fedorov V.E. Linear Sobolev Type Equations and Degenerate Semigroups of Operators. Utrecht, Boston, VSP, 2003. DOI: 10.1515/9783110915501

4. Zamyshlyaeva A.A. Linear Sobolev Type Equations of High Order. Chelyabinsk, Publishing center of SUSU, 2012. (in Russian)

5. Manakova N.A. Problems of Optimal Control for the Semilinear Sobolev Type Equations. Chelyabinsk, Publishing center of SUSU, 2012. (in Russian)

6. Sagadeeva M.A. Dihotomies of Solutions to Linear Sobolev Type Equations. Chelyabinsk, Publishing center of SUSU, 2012. (in Russian)

7. Sviridyuk G.A., Zagrebina S.A. Nonclassical Models of Mathematical Physics. Bulletin of the South Ural State University. Series: Mathematical Modelling, Programming and Computer Software, 2012, no. 40 (299), issue 14, pp. 7-18. (in Russian)

8. Al-Delfi J.K. Quasi-Sobolev Spaces $\ell_{p}^{m}$. Bulletin of the South Ural State University. Series: Mathematics. Mechanics. Physics, 2013, vol. 5, no. 1, pp. 107-109. (in Russian)

9. Sviridyuk G.A., Keller A.V. Invariant Spaces and Dichotomies of Solutions of a Class of Linear Equations of Sobolev Type. Russian Mathematics, 1997, vol. 41, no. 5, pp. 57-65. (in Russian)

10. Zamyshlyeva A.A., Al-Isawi J.K.T. Holomorphic Degenerate Operator Semigroups and Evolution Sobolev Type Equations in Quasi-Banach Spaces of Sequences. Bulletin of the South Ural State University. Series: Mathematics. Mechanics. Physics, 2015, vol. 7, no. 4, pp. 27-36. DOI: 10.14529/mmph150404 (in Russian)

11. Keller A.V., Zamyshlyaeva A.A., Sagadeeva M.A. On Integration in Quasi-Banach Spaces of Sequences. Journal of Computational and Engineering Mathematics, 2015, vol. 2, no. 1, pp. 52-56. DOI: $10.14529 /$ jcem 150106

Received September 21, 2015

УДК 517.9

DOI: $10.14529 / \mathrm{mmp} 150410$

\section{О НЕКОТОРЫХ СВОЙСТВАХ РЕШЕНИЙ ОДНОГО КЛАССА ЭВОЛЮЦИОННЫХ МАТЕМАТИЧЕСКИХ МОДЕЛЕЙ СОБОЛЕВСКОГО ТИПА В КВАЗИСОБОЛЕВЫХ ПРОСТРАНСТВАХ}

\section{А.А. Замышляева, Дюн.К.Т. Алъ-Исави}

Интерес к уравнениям соболевского типа за последнее время существенно вырос, более того возникла необходимость их рассмотрения в квазибанаховых пространствах. Причем необходимость диктуется не столько желанием пополнить теорию, сколько стремлением осмыслить неклассические модели математической физики в квазибанаховых пространствах. Заметим еще, что уравнения соболевского типа называются эволюционными, если их решения существуют только на полуоси $\mathbb{R}_{+}$. Теория голоморфных вырожденных полугрупп операторов, построенная ранее в банаховых пространствах и пространствах Фреше, переносится в квазисоболевы пространства последовательностей. Статья содержит результаты о существовании экспоненциальных дихотомий решений эволюционного уравнения соболевского типа в квазисоболевых пространствах. Для получения этого результата доказана относительно спектральная теорема и существование инвариантных пространств уравнения. 
Статья кроме введения и списка литературы содержит два параграфа. В первом определяются квазибанаховы (квазисоболевы) пространства и многочлены от квазиоператора Лапласа. Более того, приводятся условия существования вырожденных голоморфных полугрупп операторов в квазибанаховых пространствах последовательностей. Другими словами, доказывается первая часть обобщения теоремы СоломякаИосиды на квазибанаховы пространства последовательностей. Во втором параграфе строится фазовое пространство однородного уравнения, а также показывается существование инвариантных пространств уравнения. Кроме того, получены условия существования экспоненциальных дихотомий решений.

Ключевые слова: голоморфные вырожденные полугруппы; квазибанаховы пространства; квазисоболевы пространства; инвариантное пространство; экспоненциальные дихотомии решений.

\section{Литература}

1. Свиридюк, Г.А. К общей теории полугрупп операторов / Г.А. Свиридюк // Успехи математических наук. - 1994. - Т. 49, № 4. - С. 47-74.

2. Свиридюк, Г.А. Фазовые пространства полулинейных уравнений типа Соболева с относительно сильно секториальным оператором / Г.А. Свиридюк // Алгебра и анализ. 1994. - T. 6, № 5. - C. 252-272.

3. Sviridyuk, G.A. Linear Sobolev Type Equations and Degenerate Semigroups of Operators / G.A. Sviridyuk, V.E. Fedorov. - Utrecht, Boston: VSP, 2003.

4. Замышляева, А.А. Линейные уравнения соболевского типа выского порядка /А.А. Замышляева. - Челябинск: Издат. центр ЮУрГУ, 2012.

5. Манакова, Н.А. Задачи оптимального управления для полулинейных уравнений соболевского типа / Н.А. Манакова. - Челябинск: Издат. центр ЮУрГУ, 2012.

6. Сагадеева, М.А. Дихотомии решений линейных уравнений соболевского типа / М.А. Сагадеева. - Челябинск: Издат. центр ЮУрГУ, 2012.

7. Свиридюк, Г.А. Неклассические модели математической физики / Г.А. Свиридюк, С.А. Загребина // Вестник ЮУрГУ. Серия: Математическое моделирование и программирование. - 2012. - № 40 (299), вып. 14. - С. 7-18.

8. Аль-Делфи, Дж.К. Квазисоболевы пространства $\ell_{\mathrm{p}}^{\mathrm{m}} /$ Дж.К. Аль-Делфи // Вестник ЮУрГУ. Серия: Математика. Механика. Физика. - 2013. - Т. 5, № 1. - С. 107-109.

9. Свиридюк, Г.А. Инвариантные пространства и дихотомии решений одного класса линейных уравнений типа Соболева / Г.А. Свиридюк, А.В. Келлер // Известия вузов. Математика. - 1997. - № 5. - С. 60-68.

10. Замышляева, А.А. Голоморфные вырожденные полугруппы операторов и эволюционные уравнения соболевского типа в квазисоболевых пространствах последовательностей / А.А. Замышляева, Дж.К. Аль-Исави // Вестник ЮУрГУ. Серия: Математика. Механика. Физика. - 2015. - Т. 7, №4. - С. 27-36.

11. Keller, A.V. On Integration in Quasi-Banach Spaces of Sequences / A.V. Keller, A.A. Zamyshlyaeva, M.A. Sagadeeva // Journal of Computational and Engineering Mathematics. - 2015. - V. 2, № 1. - P. 52-56.

Алена Александровна Замышляева, доктор физико-математических наук, доцент, кафедра «Уравнения математической физики», Южно-Уральский государственный университет (г. Челябинск, Российская Федерация), alzama@mail.ru.

Джавад Кадим Тахир Аль-Исави, аспирант, кафедра «Уравнения математической физики», Южно-Уральский государственный университет (г. Челябинск, Российская Федерация), jtahir71@gmail.ru.

Поступила в редакцию 21 сентября 2015 г. 